\title{
Resistance, Regulation and Rights
}

\section{The Changing Status of Polish Women's Migration and Work in the 'New' Europe}

\author{
Angela Coyle \\ CITY UNIVERSITY, LONDON
}

ABSTRACT Faced with high levels of unemployment and discrimination in Poland, Polish women have made up a very large proportion of those leaving the former Communist states of central Europe, to work in EU member states. They have constituted a large undocumented migrant workforce in Europe, usually working as domestic workers and carers in the informal economy. Poland's membership of the EU is starting to regulate Polish women's work abroad and to increase their access to better paid and skilled work in the formal labour market. New marketled immigration policies in Europe are still selective and restricted however. What Polish women really need from the EU is help in securing a new framework of gender equality and equal treatment in Poland that offers hope for an improvement in their rights at home.

KEY WORDS employment rights $\bullet$ Europe $\bullet$ gender equality $\bullet$ labour markets labour migration $\bullet$ Polish women

\section{INTRODUCTION: POLISH MIGRANT WOMEN \\ IN A CHANGING EUROPE}

\section{Danuta}

I first met Danuta ${ }^{1}$ in 2000. She is 31 years old, Polish and has lived in London since 1997. She comes from a small town in eastern Poland. She used to live there with her parents and younger sister and worked as a sewing-machinist in a local clothes factory. In 1995, the factory closed down and, along with hundreds of others, Danuta lost her job. She did

European Journal of Women's Studies Copyright (c) 2007 SAGE Publications (London, Thousand Oaks and New Delhi), 1350-5068 Vol. 14(1): 37-50 http:/ / ejw.sagepub.com DOI: 10.1177/1350506807072316 
manage to find alternative work in a small factory making laundry bags, but that too was closed down just over a year later. By this time many households in Danuta's town were without work (including hers) and after several jobless months, she made the decision to leave Poland and join her elder brother in London. Having borrowed the money for her coach fare from her mother and travelling on a tourist visa, Danuta arrived in London in January 1997. She moved in with her brother, his wife and their baby son in their two-room flat in north London.

Danuta's brother had already been working in London for over a year. Each weekday morning Mondays to Fridays, he prepared and delivered sandwiches to office workers in the city; most afternoons he cleaned private houses and in the evenings and at weekends he worked as a general kitchen help in a restaurant bar in central London. Within days of her arrival Danuta joined her brother's work regime. She took on the domestic cleaning jobs of a friend of his who was pregnant and unable to continue working; the restaurant in which he worked needed some extra help and Danuta got a Saturday evening shift there working in the kitchen; and it was not long before she acquired more cleaning work through her own new network of 'clients'. Very quickly, like her brother, Danuta's days, evenings and weekends became filled with work, having her own 'portfolio' of domestic cleaning jobs along with many bunches of house keys. Within six months she was making enough money to move into her own flat with her (Polish) boyfriend and to send money to her family in Poland.

Since leaving Poland, Danuta has created her own migrant success story. It is one of hard work, self-sufficiency and independence, living within and supported by her diasporic networks in London. Although her undocumented status has meant that for most of this time, even the most ordinary transactions such as getting dental treatment, opening a bank account, installing a telephone in her flat and accessing credit were very difficult, if not impossible. Danuta did not see her family in Poland for several years as she was always fearful that if she left the UK she would not be allowed to return.

Now, however, Poland has become a member of the EU and Polish nationals now have the right to live and work in the UK. On the surface there is not much in Danuta's story that has changed. She still works as a cleaner, for the same people and on the same hourly basis but in more subtle ways her work and life are changing. Danuta is no longer fearful of leaving England and not being able to return and in the last year she has visited Poland twice; to see her mother, to have some dental treatment and to renew her passport. She has formalized her working situation by registering herself as self-employed and she is no longer totally dependent on receiving payment for her work in cash. It is a life that is much less on the margins than it used to be. Danuta cannot imagine staying in London on a permanent basis but nor can she imagine returning 'home'.

For more than a decade, Polish women like Danuta have made very good use of the new East-West 'migratory space' that opened up in Europe 
following the collapse of Communism (Morokvasic, 2003). They have constituted a significant but irregular and undocumented migrant workforce in Europe's informal economy. Job loss and unemployment in Poland have clearly pushed Polish women into finding alternative livelihoods abroad. However, this article argues that their mobility may also be seen as a form of resistance against the profound erosion of women's human rights that has occurred in the post-Communist period (for a discussion of this 'backlash', see, for example, Einhorn, 2000; Fuszara, 1997; Molyneux, 1995; Watson, 1996; World Bank, 2004). Yet without the right to live and work in Europe, Polish migrant women's lives and livelihoods have been circumscribed by their irregular status. They have had to exist outside any framework of democratic citizenship or equal rights. Although often highly educated and well qualified, they have found work primarily in low paid and low skilled jobs, especially as domestic workers, childminders and personal carers, frequently in private households.

In May 2004, however, Poland became a member of the new enlarged European Union. This article considers the significance of EU membership for Polish women's work and mobility abroad and equality at home. As they gain the right to live and work across the EU, many of the difficulties that Polish migrant women have experienced as a consequence of their undocumented and illegal status (Lutz, 2003) should ease. Skilled women should be better able to access higher level occupations. But not all Polish migrant women will necessarily benefit greatly from the increased regulation of their work in European labour markets. Rather, an end to discrimination at home in Poland would have the most impact on Polish migrant women's lives. Yet as successive Polish governments have resisted the requirement to comply with EU equality directives and continue to openly disregard the rights of women, it may be quite a while before Poland becomes a place that women neither want nor need to leave.

\section{MIGRATION AS RESISTANCE}

The numbers of women who have left Poland since 1989 to work in Western Europe are hard to quantify. Statistical data on flows to and from Poland are inadequate and based on information collected ex ante (based on an officially declared intention to leave and the planned length of stay) and take no account of either circular or irregular migration (IOM, 2004). However, it has been estimated that Polish nationals have made up the largest national group within the undocumented East-West migratory flow in Europe (IOM, 2004) and they have all but taken over both regular and irregular seasonal jobs in agriculture, construction and domestic services in Europe (Morokvasic, 2003: 109). Around 1 million Poles are thought to have sought work outside Poland every year since 1989, travelling from Poland to work in Germany, France, the Netherlands and the UK and even 
the US (Jordan and Duvell, 2002: 88). More than half of those leaving have been women (Social Agenda, 2003a).

A clear driver of this westward female migratory flow has been the high levels of job loss and unemployment in Poland that have resulted from economic restructuring and transformation to a market economy. Largescale state-run industries such as mining, textiles and clothing have been privatized and rationalized, resulting in the 'deindustrialization' of large swathes of Poland's manufacturing centres and entire local communities left without work. Women's labour market participation rates have dropped dramatically in all of the accession countries but in Poland most of all (Central Statistical Office, 2005: 7). Female economic activity rates have fallen from 52.2 percent in 1994 to 47.9 percent in 2003 (Central Statistical Office, 2005: 1) while unemployment rates in Poland are 20 percent for women and 18 percent for men and are the highest of the accession countries (Central Statistical Office, 2005: 7; Commission of the European Communities, 2003: 5). Women make up the majority of those unemployed for more than 12 months, while younger women between 18 and 34 years make up the majority of unemployed women. In some industrial regions of Poland, such as Lodz, women have made up well over 50 percent of the unemployed (Einhorn, 2000: 106). Many women, especially women over 50 , appear to have withdrawn from the labour market altogether (Central Statistical Office, 2005: 2; Women's Rights Centre, 2000: 10).

Although Polish men have been widely and adversely affected by job loss, unemployment and falling living standards, deepening gender discrimination has meant that the impact on women has been disproportionate (Gal and Kligman, 2000; World Bank, 2004). The widespread closure of state-run industries and public services resulted in women simultaneously losing both their jobs and the services that supported them, while the new private sector offers women relatively few alternative sources of employment. Indeed, the new private sector is distinguished by high levels of gender segregation, wide inequalities in pay between women and men and overt gender discrimination in employment practices (Commission of European Communities, 2003; IHFHR, 2000; World Bank, 2004). Employers routinely set age limitations on job vacancies; some even require pregnancy tests prior to employment (IHFHR, 2000: 322). They are unwilling to employ women in many categories of better paid higher skill level jobs and sexual harassment at work is widespread (UNICEF, 1999: 24).

Following its transformation to a market economy, Poland has changed from a labour market of full employment to one of widespread unemployment. Men, women, children and elderly people have all been affected in different ways, with many households experiencing dramatic falls in their income and living standards as jobs have been lost and the value of wages and state pensions has fallen (UNICEF, 1999: 3-4). While the economy may have grown overall, by 1998 living standards had dropped below 1989 levels, with a 20 percent increase in those living in poverty; 57 percent of 
whom were women (UNICEF, 1999: 5). Moreover the social crisis that has occurred in Poland has been much underplayed by the various international financial institutions driving the marketization process. Escalating health problems, alcoholism, violence (especially domestic violence), an increase in male suicide rates (especially among teenage boys) and a fall in life expectancy, are all indicators of the very high social costs of economic transformation (UNICEF, 1999).

Not only has the state rolled back its support of women's paid and unpaid work, official discourses have attempted to construct 'modern' gender relations as part of the problem. The idea that women should not be taking up the available jobs has taken a strong hold in conservative Poland. Successive governments have adopted neoconservative and profamily social policies that attempt to reconstruct anew a traditional gender regime in which men are sole family earners and women their dependants. Many childcare and reproductive health services have been withdrawn, access to contraception can be restricted and legal abortion is rarely attainable even within the very narrow scope that the law permits (IHFHR, 2000). This erosion of women's human rights resulted in Poland becoming a focus of international criticism. The UN expressed concerns about gender inequality and gender discrimination in the job market, Poland's lack of progress in tackling the growing problems of trafficking and domestic violence, the failure of the state to provide adequate advisory and support services to women, as well as the degree of influence that the Catholic Church appeared to have on government policies in particular in relation to abortion (IHFHR, 2000: 321). The EU has also added its voice to these international concerns. In preparing for accession and harmonization with European law, Poland appeared to make little effort to align itself with the requirements of the nine EU equal opportunity directives currently in place, nor with EU gender mainstreaming policies (Commission of the European Communities, 2003: 3).

It is hard to know exactly whether and how this political climate might act as a 'push' factor in women's decision to leave but their stories and narratives do seem to indicate that the vast mobilization of Polish women across Europe cannot be understood in terms of job loss and unemployment alone. Polish migrants talk of wanting to be part of a different, new and forward-looking society, 'modern' and 'global' and on the leading edge of cultural diversity (Kolankiewicz, 2006). Partly this is about social mobility and the aspiration to participate as consumers in the new global capitalism. But through their mobility, Polish women have been able to construct alternative livelihoods and worker identities and avoid becoming the gendered subjects of official conservative discourse. Mobility has enabled many women to remain economic actors; unmarried women to cohabit with their partners without censure; lesbian women (and gay men) to form same-sex relationships without discrimination (Lutz, 2003); and married women (living in a society where divorce is all but 
impossible) to achieve a socially legitimate form of marital separation. Economic transformation in Poland has been the spur to mobility, but in a climate hostile to their autonomous aspirations and desires, Polish women have used migration as a form of resistance and escape.

\section{POLISH WOMEN: A NEW PARADIGM OF TRANSNATIONAL MOBILITY AND WORK}

There is now a great deal of research on women's East-West migration and accounts of Polish women in Europe appear in a number of studies on migrant workers in Europe (see, for example, Jordan and Duvell, 2002; Kofman et al., 2000; Morokvasic, 2003). Globalization has shifted the character of international migration, away from long-term settlement towards increasingly short-term, pendular 'shuttle' mobility and with transnational lives sustained by new information technologies, diasporic communities and cheap travel. Polish women have very much been at the forefront of this new paradigm of cross-border mobility and work (Morokvasic, 2003; Wallace and Stola, 2001). Many support children and families still living in Poland, and act more like long-distance 'commuters' than migrants or settlers, travelling for relatively short periods, back and forth across national borders, between home and work.

Although, Polish labour migration in Europe has become progressively more organized since 1989, women have mostly relied on their own social capital and their capacity to access both the resources and the networks that will help them through the different stages of the migratory process. Travel into Western Europe is usually conducted legally, using one of a number of means of legal entry including tourist visas, student visas, au pair schemes, seasonal worker schemes and business visas (see, for example, Crawley, 2003; Favell and Hansen, 2002; Jordan and Duvell, 2002). Families and friends both in Poland and abroad assist with both the money and knowhow for travel (including, crucially, information for dealing with customs and immigration at the point of entry) and over time this knowledge has become much more 'expert' and extensive. On arrival, these networks have assisted with accommodation and finding work. Postcard advertisements placed in local shop windows or leaflets distributed to households in residential neighbourhoods have been one way of finding work, along with local agencies that recruit and supply cleaners and care workers to private households and residential homes. Most women, however, have relied on each other to find work and usually do so very quickly, even arriving to join an existing work rotation system (Morokvasic, 2003).

There has been a great deal of heterogeneity in how Polish women conduct their transnational lives. Polish women's cross-border mobility between Poland and Germany has been highly distinctive because 
geographical proximity and extensive and historical diasporic networks have supported frequent travel back and forth, even on a daily basis. Morokvasic suggests that in Germany at least, Polish women are a 'quasimigrant' group and better regarded as 'transnational commuters' or 'pendulaires'. They do not necessarily regard themselves as migrants, because they 'don't think of themselves as having left'; they speak of their 'travels' rather than migration and they are not at all concerned with assimilation or settlement but rather with maintaining their Polish links and identity (Morokvasic, 2003: 111-14). This is especially true for women with children who coordinate their productive and reproductive work over transnational borders (Morokvasic, 2003: 112) living out a new kind of stretched and borderless motherhood. By contrast, younger women without family dependants, and especially those who have travelled further from home (such as to the UK where very frequent travel is less sustainable), have remained outside Poland for longer periods of time. They too have no intention of long-term settlement but the longer they are away, the greater the gap between their current lifestyle and that available to them at home (Brown, 2003).

Typically Polish women have found work in private households as cleaners, childminders, au pairs and carers of the elderly, and in preparing food, washing up and serving meals and drinks in the numerous bars and restaurants of Europe's 24/7 capital cities. Helma Lutz (2003) has suggested that Polish women in Europe have occupied a kind of 'twilight zone' with regard to both their illicit residence and undeclared work. This status has arisen not so much from illegal entry but from overstaying the duration of their visa and working without a work permit. Without rights to employment and residency, Polish women have not benefited from the many rights that accompany citizenship, such as the use of welfare and health services, education and training, regularized work and employment benefits or protection from discrimination, harassment and exploitation in work. Yet as white women they are more easily absorbed into existing national ethnic hierarchies and are usually less fearful than other undocumented migrant groups of detection. Working in private households can be very isolating but it has offered some 'cover' for undocumented status.

What is most striking about Polish migrants' experience is not their undocumented status however, but their self-sufficient 'worker accounts' (Jordan and Duvell, 2002: 103). They work long hours for low pay often with no contract, making no claims on state welfare services while being 'inconspicuously useful' in a wide range of jobs (Jordan and Duvell, 2002: 112-13). It is a life in which they do not necessarily need to move outside their diasporic networks. The connection to their country of residence can be restricted to the houses they clean, the children they look after and the meals they serve. Language skills need only be honed to cope with their 'temporary' transnational life. 


\section{REGULATION IN THE `NEW’ EUROPE}

Polish women may have displayed little interest in permanent settlement outside Poland but nevertheless there is a limit to what they can achieve through their mobility while they remain outside a framework of citizenship and rights. Mobility has empowered Polish women to the extent that they have been able to construct and sustain commuter and worker identities, in the face of strong official efforts to construct women as dependent. Yet as Erel (2003) has suggested, to be empowered by migration women need their skills to be recognized, to speak the language of their country of residence and for their social networks to extend beyond their migrant group. All of which has been difficult for Polish women - their work made illegal by immigration policies that are out of step with the logic and ethos of globalization and transnationalism.

As new nationals of an enlarged EU, Polish women's fortunes, both inside and outside Poland, could change. Poland has the highest levels of female educational attainment in Europe (Eurostat, 2005) and there is a 'startling' number of skilled workers among Polish migrants (Jordan and Duvell, 2002: 133), but the opportunities to gain formal recognition of their skills and qualifications and to secure access to well-paid skilled work in the formal economy depend on how Europe's new transnational migration strategy will be implemented in practice. It is immigration policies, rather than employment policies that are key in shaping the job status of migrants (Kofman et al., 2000: 114). The status of Polish migrant women in the 'new' Europe is currently caught in an 'old' Europe, somewhat divided between adopting more market-driven 'open door' policies and maintaining Fortress Europe.

The fall of the Berlin Wall and war in Yugoslavia were unanticipated events in Europe that triggered vast levels of mass cross-border mobilization for which Western Europe was totally unprepared. Since that time, the EU has attempted to pursue a managed approach to the integration of Central and Eastern Europe into an enlarged Europe (Jordan and Duvell, 2002). In 1993, the 'Copenhagen Summit' agreed the economic and political criteria under which Central and Eastern European countries could bid for EU membership and in 1994 both Hungary and Poland made their first bid to join the EU under the 'Copenhagen Criteria' (Dustmann et al., 2003: 10). In 2002, the EU finally agreed that Poland along with seven other countries would join the EU in 2004 followed by Bulgaria and Romania joining in 2007. Membership of the EU will eventually give Polish nationals, along with the citizens of the other accession countries, the right to study, reside and work in the other EU member states.

However, the extension of the EU in May 2004 to include eight new member states, of which Poland with a population of nearly 39 million is the largest, exposed a deep schism in Europe's official response to migration and cross-border controls. Across the EU, there has been a distinctive shift towards a more transnational approach to migration policies (Sassen, 
1999) along with an official recognition of some of the benefits of labour migration (Social Agenda, 2003a). An ageing and shrinking working population across the EU has meant that immigration is now the main source of population growth and necessary to meet current and future labour supply needs (Social Agenda, 2003a). There is also an official recognition that policy approaches that have attempted to control migration have not been particularly effective. Increased restrictions are often counterproductive, leading to more breaches of migration laws and more clandestine activity (Favell and Hansen, 2002; Jordan and Duvell, 2002: 3). The size of the informal economy in Europe is now estimated to be between 7 percent and 16 percent of EU GDP or around 10-28 million jobs and brings with it many problems associated with unregulated work (Social Agenda, 2003b). Since October 2003, as part of the updated European Employment Strategy, all EU member states have been required to adopt new policy approaches for regularizing the informal economy and in particular with undocumented work, much of which is undertaken by migrant labour.

This official shift towards a more 'open door' approach in EU policy has been in conflict, however, with the concerns of individual member states who fear that an increase in migrants from the new member states in Central and Eastern Europe will significantly add to existing levels of immigration. Rather than moving to a more liberal approach, France, for example, has introduced many new measures to control migration, while the Netherlands has moved from the liberal open door policy it held throughout most of the 1990s to one of greater protectionism. Claiming the need to protect public infrastructures and the welfare rights of existing citizens, most EU member states, including Italy, Austria, Finland, France, Germany and the Netherlands, have imposed transitional arrangements that will in some cases restrict the employment and welfare rights of nationals from the new member countries for up to seven years after enlargement, until 2011. Germany in particular is experiencing historically unprecedented high levels of unemployment and, in conjunction with populist fears that geographical proximity and large historic diasporic Polish communities within Germany will continue to support extensive migratory flows across its borders with Poland, is unlikely to adopt a more liberal stance on Polish migration. Poland is now itself a migrant-receiving country and the perceived porosity of Poland's border with the rest of Eastern Europe fuels German concerns that they will receive new flows from countries such as the Ukraine via Poland's eastern 'back door' (see, for example, Kindler [2005] on how Ukrainian migrants have all but taken over undocumented domestic work in Poland).

Exceptionally, the UK, Ireland and Sweden, who all anticipated low levels of new migration following enlargement (Dustmann et al., 2003) adopted an open door policy on nationals from the new EU member states from the first day of enlargement. They had an interest in regularizing the status of both existing undocumented migrants, as well as new inflows from the accession countries, in order to improve the selective 
recruitment of skilled migrants (Jordan and Duvell, 2002: 79) - and especially for those sectors and labour markets in which women predominate, such as health and social care where an ageing population is resulting in a very significant demand for health and social care workers (Hutton and Giddens, 2001). Since May 2004, Polish teachers have been permitted to teach in any EU country and in both Sweden and the UK new schemes have been introduced to assist in the recruitment of registered nurses and doctors from Poland. However, immigration policies based on labour market demand are selective (Favell and Hansen, 2002) and as yet 'old' Europe does not extend to all citizens from the newly included EU states of Central Europe, the right to study, reside and live in any EU member state. Such a borderless EU labour market is still some way off.

\section{RIGHTS AT HOME}

Regularized status is of great benefit to qualified women who want full-time and permanent work and who have perhaps worked previously in unskilled jobs. These new rights are of less help to those women without highly marketable skills, or to those without bilingual skills, or to the many Polish migrant women who have to take their family and care responsibilities in Poland into account and who want flexible and shortterm work. Although work in the informal economy has offered none of the protection or benefits of the regularized work, it has given Polish women a degree of flexibility that is not available in the formal labour market. The right to work across the EU is an important benchmark but one of which relatively few Polish women can take advantage.

On 1 May 2004, the position of Polish migrants living and working in the UK was regularized. It is regarded as a successful paradigm of labour market extension and regularization. All Polish nationals working in the UK illegally were granted an amnesty and acquired the right to live and work in the UK provided they registered as employees under the Workers' Registration Scheme (WRS). All those working legally but under restricted employment schemes, such as those employed as au pairs or seasonal agricultural workers, or on a working student's visa, acquired the right to move to different jobs in different sectors and remain permanently. Although the majority of Polish migrants are still travelling to Germany to work, since May 2004 the numbers of Polish nationals entering the UK and Ireland has increased beyond all expectations, with around half a million entering the UK, and a further 200,000 entering Ireland. Post-2004, Polish nationals in the UK continue to maintain very strong links and interests in Poland and this is made easier by the ability to make frequent return visits often as much as 10 times a year (Garapich, 2006). It is also easier for migrants from Central and East European to find work, change jobs 
and in some cases, to move into higher level occupations; although many still remain in low paid, insecure work, working below their skill levels (Anderson et al., 2006). But whereas women appeared once to make up the majority of Polish nationals entering the UK, since 2004 this gender distribution seems to have changed. Men made up 57 percent of those registered on the WRS, while the Labour Force Survey suggests that more Polish men than women are entering the UK post-2004 (Labour Force Survey, 2005, cited in Drinkwater, 2006). It is most likely, however, that Polish women are still undercounted and many continue to occupy secondary and contingent labour markets where there are fewer benefits to be gained from regularized work, and less incentive to register. It is hard to believe that improvements at home are finally stemming the flow.

In 2006, two years after EU enlargement, the economic and social situation in Poland remains unchanged. Unemployment levels are high at around 20 percent (40 percent for those under 18), only half the working age population is economically active, while 18 percent of Poles are living below the official poverty line. Unemployment and poverty are particularly acute in rural areas, which account for over a third of the Polish population. Polish manufacturing industries are unable to compete with other global producers (especially China). Meantime, Poland itself has become a receiving country for migrant workers from other Central and Eastern European countries, who are now the preferred labour supply for low waged jobs in the informal sector. The EU is supporting significant business and infrastructure development in Poland, and cities such as Warsaw and Krakow are vibrant and cosmopolitan places where a new European modernity is much in evidence. But underneath lies a vast pool of surplus of labour that continues to look to Europe for alternative sources of income and work and labour market gender discrimination is still unchecked.

In 2001, the Government Plenipotentiary for the Equal Status of Women and Men was set up in response to the EU requirement that Poland develop a national institutional framework for gender equality in Poland; in compliance with the European Council's strategy on equal treatment and gender mainstreaming and including the goal of achieving 60 percent female employment by 2010. The EU funded the creation of a new national database of gender disaggregated statistics so that the Plenipotentiary could monitor the effectiveness of gender mainstreaming polices and in 2005 the Plenipotentiary launched an information campaign informing women of their new rights under EU directives. In this short period, many leading Polish feminist academics and activists contributed their expertise to the work of the Plenipotentiary, and there was a hope that EU gender equality strategies could finally make a difference in Poland. However, both official and public support for the Plenipotentiary over this period was at best lukewarm and following a general election in November 2005, an ultra-conservative, pro-family and 'avowedly Catholic' (The Economist, 
2006) government coalition came into power. Part of its populist appeal was based on an anti-EU stance and one of its first acts was to disband the Plenipotentiary for the Equal Status of Women and Men. The hope that Europe might provide a framework for combating labour market discrimination and gender inequality in Poland still seems a long way off.

Coincidentally as I was finishing this article, I received an email from Kasia, a friend in Warsaw. She wrote: 'the political situation is horrible, a giant backlash, conservatism, xenophobia, homophobia, you name it. I am thinking about emigration again.'

\section{CONCLUSION}

This article has discussed how faced with job loss, unemployment and gender discrimination, many Polish women opted to leave Poland to find work in Europe. Since the 1990s, Polish women have seized the new opportunity for mobility in very large numbers, travelling to work in the informal economies of Europe as cleaners, nannies, childminders and carers. In doing so, many Polish women have forged new patterns of transnational work and family organization, appearing more like 'commuters' than migrants as they travel back and forth to work, across national borders on a regular basis. In many respects, Polish women have been very successful in maintaining worker identities through this mobility but nevertheless, without work permits or rights of residency, their status has been undocumented, and without employment rights or recognition of their qualifications, their work has been precarious and unskilled.

The accession of Poland to the EU has the potential to regularize Polish migrant women's work and to help them access work that is commensurate to their skills and qualifications. But continuing migration controls in Europe are highly selective and will continue to restrict Polish women's employment rights in Europe, for some years to come. And anyway, relatively few Polish women have an interest in longer term settlement outside Poland. So far, however, membership of the EU has failed to make an impact on gender discrimination in Poland, which is widespread and routine and it may be a long while yet before Poland becomes a place to which Danuta will want to return. What she and most Polish women need from the EU is a legal framework of gender equality and rights in Poland that will enable them to stay at home.

\section{NOTE}

My thanks to Helma Lutz for her helpful comments on this article.

1. This biography is taken from work in progress on migrant women's narratives. This is a fictional name adopted to preserve anonymity. 


\section{REFERENCES}

Anderson, B., M. Ruhs, B. Rogaly and S. Spencer (2006) Fair Enough? Central and East European Migrants in Low-Wage Employment in the UK. York: Joseph Rowntree Foundation; at: www.compass.ox.ac.uk/changingstatus

Brown, B. (2003) 'Being a Migrant the Polish Way', openDemocracy; at: www.opendemocracy.net/people-igrationeurope/article_1300.jsp (accessed 2 June 2006).

Central Statistical Office (2005) Women and Men on the Labour Market. Warsaw: Central Statistical Office; at: www.stat.gov.pl/english/dane_spolgosp/prludnosc/kob_mez_praca/index.htm (accessed 2 June 2006).

Commission of the European Communities (2003) Annual Report on Equal Opportunities for Women and Men in the European Union 2002. Brussels: Commission of the European Communities.

Crawley, H. (2003) 'Managing Migration: Current Entry Routes into the UK Labour Market', paper presented to the Athens workshop 'Managing Migration for the Benefit of Europe', Institute of Public Policy Research (IPPR), 31 January-1 February 2003; at: ippr.org.uk/uploadedFiles/ projects/Athens1.doc (accessed 2 June 2006).

Drinkwater, S. (2006) 'The Changing Face of the Polish-Born Population in the $\mathrm{UK}^{\prime}$, paper presented at conference on 'London's Polish Borders', CRONEM, University of Surrey and the Consulate General of the Republic of Poland, London.

Dustmann, C., M. Casanova, M. Fertig, I. Preston and C. Schmidt (2003) The Impact of EU Enlargement on Migration Flows, Home Office Online Report 25/03. London: Research, Development and Statistics Directorate, Home Office; at: www.homeoffice.gov.uk/rds/pdfs2/rdsolr2503.pdf (accessed 2 June 2006).

Einhorn, B. (2000) 'Gender and Citizenship in the Context of Democratisation and Economic Reform in East Central Europe', pp. 103-24 in S. Rai (ed.) International Perspectives on Gender and Democratisation. Basingstoke: Macmillan.

Erel, U. (2003) 'Skilled Migrant Women and Citizenship', pp. 261-84 in M. Morokvasic-Muller, U. Erel and K. Shinozaki (eds) Crossing Borders and Shifting Boundaries Vol. 1: Gender on the Move. Opladen: Leske and Budrich.

Eurostat (2005) Europe in Figures: Eurostat Year Book. Luxembourg: Eurostat.

Favell, A. and R. Hansen (2002) 'Markets against Politics: Migration, EU Enlargement and the Idea of Europe', Journal of Ethnic and Migration Studies 28(4): 581-602.

Fuszara, M. (1997) 'Women's Movements in Poland', pp. 128-42 in J.W. Scott, C. Caplan and D. Keates (eds) Transitions, Environments, Translations. New York and London: Routledge.

Gal, S. and G. Kligman (2000) The Politics of Gender after Socialism: A ComparativeHistorical Essay. Princeton, NJ: Princeton University Press.

Garapich, M. (2006) 'Class and Ethnicity of Global City Migrants', paper presented at conference on 'London's Polish Borders', CRONEM, University of Surrey and the Consulate General of the Republic of Poland, London.

Hutton, W. and A. Giddens, eds (2001) On the Edge. London: Verso.

IHFHR (International Helsinki Federation for Human Rights) (2000) Women 2000: An Investigation into the Status of Women's Rights in the Former Soviet Union and Central and South Eastern Europe. Vienna, IHFHR; at: www. ihfhr.org/ documents/doc_summary.php?sec_id=3\&d_id=1470 (accessed 2 June 2006).

IOM (Institute of Migration) (2004) Migration Trends in Selected EU Applicant Countries, Volume III, Poland: Dilemmas of a Sending and Receiving Country. Geneva: IOM. 
Jordan, B. and F. Duvell (2002) Irregular Migration; The Dilemmas of Transnational Mobility. Cheltenham and Northampton, MA: Edward Elgar.

Kindler, M. (2005) 'Migrant Domestic Workers in Poland - Balancing the Risks', paper presented at the international conference on 'Migration and Domestic Work in Global Perspective', The Netherlands Institute for Advanced Studies, Wassenaar.

Kofman, E., A. Phizacklea, P. Raghuram and R. Sales (2000) Gender and International Migration in Europe. London and New York: Routledge.

Kolankiewicz, G. (2006) 'The Challenge of Recent Polish-UK Migration for Diasporic Citizenship', keynote speech at conference on 'London's Polish Borders', CRONEM, University of Surrey and the Consulate General of the Republic of Poland, London.

Lutz, H. (2003) 'Living in the Twilight Zone; Illegalised Migrant Domestic Workers in Germany', paper presented at 'Domestic Service, a Factor of Social Revival in Europe', workshop, Essex University, 8-11 May.

Molyneux, M. (1996) 'Women's Rights and the International Context in the Post Communist States', pp. 232-59 in M. Threfall (ed.) Mapping the Women's Movement. London: Verso.

Morokvasic, M. (2003) 'Transnational Mobility and Gender: a view from Post-Wall Europe', pp. 101-33 in M. Morokvasic-Muller, U. Erel and K. Shinozaki (eds) Crossing Borders and Shifting Boundaries Vol. 1: Gender on the Move. Opladen: Leske and Budrich.

Sassen, S. (1999) Guests and Aliens. New York: The New Press.

Social Agenda (2003a) Issue No. 6 July. Brussels: European Commission Employment and Social Affairs.

Social Agenda (2003b) Issue No. 7 December. Brussels: European Commission Employment and Social Affairs.

The Economist (2006) 'Survey of Poland', 13 May.

UNICEF (1999) After the Fall; The Human Impact of Ten Years of Transition, The MONEE Project. Florence: UNICEF Innocenti Research Centre; at: www.unicef-icdc.org/publications (accessed 2 June 2006).

Wallace, C. and D. Stola, eds (2001) Patterns of Migration in Central Europe. London: Palgrave.

Watson, P. (1996) 'The Rise of Masculinism in Eastern Europe', in M. Threlfall (ed.) Mapping the Women's Movement. London and New York: Verso.

Women's Rights Centre (2000) 'Polish Women in the 1990s', Warsaw; at: www.free.ngo.pl/temida/labor.htm (accessed 2 June 2006).

World Bank (2004) Gender and Equal Opportunities in Poland: Has Transition Left Women Behind?, Report No. 29205, March. Geneva: Poverty Reduction and Economic Management Unit Europe and Central Asia Region, World Bank.

Angela Coyle is Professor of Sociology at City University, London. She has a longstanding interest in gender and employment and gender in organizations, and has published widely on these issues. She has worked with women's organizations in Poland for more than a decade. Over 2004-5, she led the research team that set up a new gender statistics database for the Plenipotentiary for the Equal Status of Women and Men in Poland. Address: Department of Sociology, City University, Northampton Square, London EC1V OHB, UK. [email: a.i.coyle@city.ac.uk] 